\title{
The model influence of authoritarian parenting, extraversion personality, and conformity to bullying among students
}

\author{
Pipih Muhopilah, Fatwa Tentama, Yuzarion \\ Faculty of Psychology, Universitas Ahmad Dahlan, Yogyakarta, Indonesia
}

\begin{tabular}{l} 
Article Info \\
\hline Article history: \\
Received Aug 6, 2020 \\
Revised Mar 5, 2021 \\
Accepted Apr 10, 2021 \\
\hline
\end{tabular}

Keywords:

Authoritarian parenting

Bullying

Conformity

Extraversion personality

\begin{abstract}
The purpose of this study was to analyze the model of the influence of authoritarian parenting, extraversion personality, and conformity to bullying in students. The population in this study were all students of grade eight of $\mathrm{X}, \mathrm{Y}, \mathrm{Z}$ state middle school in Yogyakarta, consisting of 524 students. The sample in this study was 185 students. The sampling technique used in this study was cluster random sampling. The data were collected with the scales which were developed for each variable studied. Data analysis was performed by testing the outer and inner models using structural equation model (SEM) through the Smart Partial Least Square 3.2.8 program. The results of this study were the formation of the model of the influence of authoritarian parenting, extraversion personality, and conformity to bullying that was found to be fit with empirical data. Overall, the findings suggested that all variables under investigation (authoritarian parenting, extraversion personality, and conformity) had positive and a very significant influence on bullying. This model can be used as a valid reference in developing bullying variables.
\end{abstract}

This is an open access article under the CC BY-SA license.

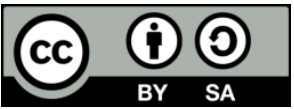

\section{Corresponding Author:}

Fatwa Tentama

Faculty of Psychology

Universitas Ahmad Dahlan

Kapas Street 9, Umbulharjo, Yogyakarta, Indonesia

Email: fatwa.tentama@psy.uad.ac.id

\section{INTRODUCTION}

Schools are institutions that aim to provide education for students. This aim, however, is hampered by bullying [1]. Bullying is a conscious, repetitive and deliberate action of hurting and threatening people of lower position by aggression which aim to create terror [2]. Bullying can be in the form of seductive behavior, insulting, mocking, or other actions that can cause physical and mental damage [3]. Bullying has been found to occur in various cultures [4] and has resulted in various negative effects on both the victims and perpetrators [5]. Victims of bullying can experience social anxiety [6], depression [7], decreased mental health and thinking capacity [8], [9], and can further trigger suicide attempts [10], [11]. In the academic context, bullying victims often feel afraid to go to school [12], so that they are at risk of missing classes more frequently [13]. They also experience a decline in academic achievement [14], [15], which might further result in school dropouts [16]. Victims of bullying can also turn out to be the perpetrators of bullying in the future [17]. Besides negative effects for victims, bullying also causes various negative effects for perpetrators.

Bullying actors tend to perform delinquent behavior [18], such as drug abuse [19]. They can also experience decreased empathy [20], and increased aggressive behavior [21]. Such behavior can also influence bullying perpetrator to get accustomed to coercion [22] and increased anti-social behavior [23]. They also possess a higher possibility of being disliked by friends, which can cause negative feelings about the future [24], and potentially mental health problems [25]. Bullying is a condition in the form of negative 
and repetitive behavior, that is when individuals find it difficult to defend themselves from an unbalanced force and the negative treatment, which is done intentionally and intensely [2]. Bullying is done based on the desire to insult and humiliate others [26]. Bullying targets can be individuals or groups who do not have the power to avoid, stop, or protect themselves [27].

Dixon and Smith [27] suggest several forms of bullying, namely: 1) Physical bullying, including beating, kicking, punching, taking or damaging the victim's belongings, locking the victim in the room, and extortion; 2) Verbal bullying includes teasing, mocking, threatening, calling with hurtful calls, insulting, calling with words that hurt the victim's sexual orientation, ethnic groups, culture, learning difficulties, and so on; 3) Social exclusion is the systematic treatment of removing someone from his social group or intimidation. Exclusion can occur directly by expelling the victims from the group or indirectly by influencing group members to excommunicate them; 4) Indirect bullying includes the spread of bad news, inviting others to stay away from the victim, lying or spreading false rumors about the victim, or sending certain information so that other people do not like the victims.

A number of family characteristics are associated with bullying [27], one of which is parenting [28], [29]. Martínez, et al. [30] suggest that authoritarian parenting is closely related to bullying. According to Baumrind [31], authoritarian parenting is a parenting style that seeks to shape, control, and evaluate children's behavior and attitudes according to their parents' standards of behavior. Parents do not allow discussion and require children to follow various rules they make. Authoritarian parenting emphasizes very high levels of behavioral control with low acceptance [32] and strict, uncompromising type of parenting, which allow the use of punishment [33].

Robinson, et al. [32] propose several characteristics of authoritarian parenting, which include verbal hostility. This particular characteristic is associated with a parenting style that uses verbal attack shown by scolding a child with explosive anger, shouting when a child misbehaves, arguing with a child, and show disagreement on the child's behavior by disputing. Secondly, corporal punishment is also common in this type of parenting. It is a physical punishment used as a method of discipline. Punishment can be demonstrated by hitting when the child is disobedient to parents, slapping when the child behaves badly, holding the child roughly when the child is disobedient, telling the child to do something by threatening to punish without giving rationalization and so on. In addition to that, nonreasoning punitive strategies are also associated with authoritarian parenting. This is done by giving punishment in the form of taking the rights of the child without explaining the reason, punishing by leaving the child alone in a certain place, giving punishment before asking why the child committed an offense, and not paying attention to the child's feelings and more concerned with parent's own feelings. Directiveness is characterized by always telling children what to do, demanding to do or do something, giving reprimands and criticism to improve children's behavior, including criticizing the child's behavior that is seen to be inappropriate by parents.

Children's experiences with family and parenting styles play a role in shaping children's capacity to adapt in school and influencing the relationship between children and their peers [34]. Children with authoritarian parenting tend to fail to develop environmental awareness because they are accustomed to receiving physical punishment from parents [35], thus making children more at risk of bullying [30]. Authoritarian parenting supports the use of punishment as an effort to discipline children, which may increase the risk of bullying [29]. The results of Hong, Kim, and Piquero [36] research shows that parental punishment is directly related to bullying.

Besides authoritarian parenting, another factor influencing bullying is personality [37]. According to Mitsopoulou, et al. [38], personality associated with bullying is an extraversion personality. Extraversion personality represents individuals who are easy to get along with, active, and oriented towards others [39]. Extraversion describes the extent to which a person is attracted to other people and events in the external world. Individuals with these traits tend to be extroverted, outgoing, energetic, and talkative [40]. When involved in group activities, individuals with high extraversion tend to dominate [41]. There are six aspects of extraversion personality. Firstly, warmth is shown by the style of interaction that is friendly and the ability to build an attachment to others. Gregariousness (the desire to be with others) is characterized by the love of being in the crowd and talking. These kinds of people do not have a lot of worries and have a kind of social stimuli. Assertiveness is the ability to lead, to accept change, to think in their own way, and to express their feelings and desires. In addition, the activity level is the busyness of acting with enthusiasm, agility, delight with the task given, talking quickly, authenticity, and strength. People with this trait is also an excitement seeker. They like challenging environments and activities and always look for fun. Finally, they also have positive emotions, which is shown by the desire to look for joy, excitement, and an exciting life [39].

Bullying can emphasize the position of an individual in social situations. Individuals who are assertive will be more active in starting conflicts with others [42], [43]. This is because they tend to use bullying as a way to increase their social status [44]. Bullying tends to be carried out by individuals who have high levels of extraversion [45], and extraversion can significantly be a positive predictor for bullying [46]. 
However, a number of other research results show no influence between extraversion personality and bullying, as in the results of Farrington, et al. [23], Igundunasse, et al. [47], Book, et al. [48], Van Geel, et al. [49]. According to Bollmer, Harris, and Milich [50], although there are previous studies that suggest the influence and relationship of extraversion personality and bullying behavior, the influence and relationship occur inconsistently, so that further research is still needed.

The next factor that influences bullying is the peer factor. Friends can provide reinforcement to the perpetrators of bullying, both with active and passive reinforcement, thereby increasing the risk of bullying [51]. When an individual prioritizes friend acceptance, he/she can use aggression to gain power and status among their peers [20]. The influence of peers has been proven to be significant for bullying, and this is influenced by individual conformity in antisocial behavior by their peers [52]. Conformity is a condition in which an individual tries to adjust to the situation in a social group because they feel there is a demand or pressure to display the same behavior as their social group [53]. Confidence enables individuals to change their attitudes, behaviors [54], and beliefs to have attitudes that are the same as others [55]. Confidence consists of several aspects, and one of which is compactness. The existence of groups makes individuals endeavor to adjust to the condition in their group. Cohesiveness is based on what is preferred within the group, making individuals tend not to have the courage to make deviations, because it will cause group rejection. In addition to that, there is an aspect of the agreement, which is the pressure to follow every decision in a group. Disagreement, therefore, will lead to reduced trust between individuals in the group. Subsequently, those who differ in terms of opinion will also be considered deviant. In the obedience aspect, individuals are willing to do something they don't want to do. This can happen because of social pressure in the form of punishment or threats from within the group so that individuals always try to fulfill group expectations [53].

Teenagers spend a lot of time with their friends at school, in the home environment, in a community, and social media. Bullying almost always occurs in the context of friendship. Making friends with people who do bullying can turn someone into one because it is associated with higher levels of bullying [56]. Conformity is one reason individuals commit bullying [57] and take the initiative to maintain bullying [58]. This is because friends can provide reinforcement to carry out bullying [51]. When students prioritize peer acceptance, teens can use bullying as a way to gain power and status among their peers [20]. The influence of peers proved to be significant for bullying, and this, among other things, was influenced by individual conformity in antisocial behavior by their peers [52]. However, other research shows that conformity does not affect bullying [59]-[61]. The inconsistency of the results of the study indicates the need for further research.

Previous studies have discussed the phenomenon of bullying, various variables, and various methods. However, the dynamics of bullying continue to develop, so researchers propose to use a new approach to understanding bullying behavior. The novelty in this study is: 1) This research was conducted to design a bullying model and test the model so that a suitable bullying model will be produced; 2) The data analysis techniques used was the structural equation model (SEM) through the partial least square (PLS) program.

Based on the background of the problem that has been described and supported by previous studies' results, the researcher wants to further explore how authoritarian parenting, extraversion personality, and conformity to bullying behavior. The purposes of this study are to design a theoretical model of the relationship between bullying and other variables such as authoritarian parenting and examine whether the theoretical models that describe the influence of the aforementioned variables (authoritarian parenting, extraversion personality, and conformity) to bullying in students fit with empirical data obtained from this study. Secondly, it also further aims to examine the effect of authoritarian parenting on bullying in students. This study also aims to examine the effect of extraversion on bullying in students and finally to examine the impact of conformity on bullying in students.

\section{RESEARCH METHOD}

\subsection{Population and sample}

This study population were all eighth-grade students of $\mathrm{X}, \mathrm{Y}$, and $\mathrm{Z}$ state middle school in Yogyakarta with 524 students. The sample in this study was 185 students consisting of 98 males and 87 females with age range of 13-16 years (means=14 years). The sampling technique was cluster random sampling.

\subsection{Research instruments}

The instrument used to collect the data for the present study was a psychological scale consisting of four scales, namely the bullying scale, the authoritarian parenting scale, the extraversion personality scale, and the conformity scale. The scaling model used consists of two models, namely the semantic differential scaling model with an answer choice of 1-5, which was used for the bullying scale and extraversion personality scale. The other model was the Likert scaling model with an answer choice of 1-5 used for the 
authoritarian parenting and conformity scale. The bullying scale was arranged by the researcher by referring to the forms of bullying from Dixon and Smith [27] consisting of physical bullying, verbal bullying, social exclusion, and indirect bullying. The authoritarian parenting scale was arranged by researchers with reference to the characteristics of authoritarian parenting according to Robinson, et al. [32] consisting of four characteristics, namely verbal hostility, corporal punishment, nonreasoning/punitive strategies, and directiveness. Extraversion personality scale was designed by referring to the characteristics of extraversion personality according to McCare and Costa [39], these characteristics are, warmth, gregariousness, assertiveness, activity level, excitement seeking, and positive emotions. Conformity scale compiled by researchers with reference to aspects proposed by Taylor, et al. [53], which consists of three aspects, namely cohesiveness, agreement, and obedience.

Examples of items on the scale of authoritarian parenting are "The work I do must be in accordance with the wishes of parents", "The punishment given by parents depends on their mood", "Parents give punishment without explaining my mistakes". Examples of items on the conformity scale are "I and my friends have the same thought", "I follow the advice given by friends" and "I feel confident when with friends". Then examples of items on the extraversion personality scale and bullying scale can be seen in Table 1 and Table 2.

Table 1. Sample items from extraversion personality scale

\begin{tabular}{cccccc}
\hline \multicolumn{6}{c}{ Activities that I do are } \\
\hline Monotonous & 1 & 2 & 3 & 4 & Various \\
Easy & 1 & 2 & 3 & 4 & Complicated \\
Safe & 1 & 2 & 3 & 4 & Risky \\
\hline
\end{tabular}

Table 2. Sample items from bullying scale

\begin{tabular}{cccccc}
\hline \multicolumn{5}{c}{ Activities that I do are } \\
\hline Tolerate & 1 & 2 & 3 & 4 & Punish \\
Give advice & 1 & 2 & 3 & 4 & Scold \\
$\begin{array}{c}\text { Take care of their } \\
\text { belongings }\end{array}$ & 1 & 2 & 3 & 4 & Damage \\
\hline
\end{tabular}

\subsection{Validity and reliability}

Testing research instruments with SEM-PLS is called the measurement evaluation model or the outer model. Measurement of outer models is carried out to measure the models' validity and reliability [62]. Validity test using PLS consists of two tests of validity, namely convergent validity, and discriminant validity. A convergent validity test is carried out to measure the gauges (manifest variable) of a construct. Convergent validity on reflective indicators can be appropriate based on the loading factor value on each indicator. Values containing factors are used to declare whether or not a construct is $>0.4$ [63] and average variance extracted (AVE) value of $>0.5$ [62]. Discriminant validity is revealed by comparing the root of the average variance extracted (AVE) in each construct with the value of the average root variance extracted (AVE) in the construct or other variables. Good discriminant validity is indicated by the average root exchange rate of average variance extracted (AVE), a construct that has higher the average root exchange rate of average variance extracted (AVE) with other constructs [62]. Reliability testing using SEM-PLS analysis can be done in two ways, namely with composite reliability and Cronbach alpha. The construct was declared to be reliably approved if it possesses a Cronbach alpha value of $>0.6$ [62] and composite reliability values of $>0.7$ [63].

\subsection{Data analysis method}

The data gathered were analyzed with confirmatory factor analysis (CFA) using partial least square (PLS) through smartPLS software version 3.2.8. developed by Wold in 1974 [62]. Outer models are used to determine the construct validity and reliability. The direction of the indicator determines the use of the outer model evaluation method type. The next stage is evaluating the inner model in three ways, namely; First, by looking at the value of the determinant coefficient $\left(\mathrm{R}^{2}\right)$ to measure the level of variation in changes in exogenous variables towards endogenous variables. If $\mathrm{R}^{2}>0.2$, then the proposed prediction model is getting better. Second, looking at the predictive relevance $\left(\mathrm{Q}^{2}\right)$ value is done to measure how well the model's observed value is generated. The estimated parameters $\mathrm{Q}^{2}$ value of $>0$ indicates that the model has predictive relevance. Third, the GoF index is also used. It is an index that describes the overall suitability of the model calculated from the predicted model's squared residuals compared to the actual data. The criteria for a GoF value of 0.1 are small (GoF small), 0.25 (GoF moderate), 0.36 (GoF large) [62].

Exogenous construct hypothesis testing for endogenous constructs is done by testing predictive relevance, using the bootstrapping resampling method developed by Geisser [62]. The test statistic used was the t-test, the t-statistic value of 5\% was 1.96. Hypothesis testing using smartPLS version 3.2.8. The hypothesis is accepted if the p-value significance is $<0.05$, and the hypothesis is rejected if the significance value is $>0.05$. 


\section{RESULTS AND DISCUSSION}

The results in this study are divided into two parts, namely the results of outer model testing and the results of inner model testing. Outer model testing aims to test the measurement model, and the inner model testing aims to test the structural model.

\subsection{Test result of the measurement model}

The outer model analysis includes convergent validity test, discriminant validity test, composite reliability test, and Cronbach alpha reliability test.

\subsubsection{Convergent validity test}

Convergent validity can be seen from the loading factor value on each indicator (item) and the value of average variance extracted (AVE). A scale is said to meet convergent validity if the loading factor value of each item is $>0.4$, and the average variance extracted (AVE) value of each variable is $>0.5$ [63]. The details of the loading factor and AVE value of each variable can be seen in Table 3.

Table 3. Loading factor and AVE value

\begin{tabular}{lccc}
\hline \multicolumn{1}{c}{ Variable } & Loading factor & Average variance extracted & Explanation \\
\hline Bullying & $0.424-0.850$ & 0.509 & Valid \\
Authoritarian parenting & $0.405-0.977$ & 0.533 & Valid \\
Extraversion personality & $0.456-0.915$ & 0.514 & Valid \\
Conformity & $0.475-0.967$ & 0.515 & Valid \\
\hline
\end{tabular}

Based on Table 3, it is known that the loading factor value and the average variance extracted (AVE) value of each variable have fulfilled the criteria so that it can be concluded that all research variables have met the requirements of convergent validity.

\subsubsection{Discriminant validity test}

Discriminant validity can be seen by comparing the average variance extracted (AVE) root value between variables. A scale is said to be valid if the average variance extracted (AVE) root correlation value of each variable is higher than the average variance extracted (AVE) root correlation value with other variables [63]. The root value of the average variance extracted (AVE) in this study can be seen in Table 4.

Table 4. Root value of average variance extracted (AVE) of bullying, authoritarian parenting, extraversion personality, and conformity

\begin{tabular}{lcccc}
\hline & Bullying & Authoritarian parenting & Extraversion personality & Conformity \\
\hline Bullying & 0.713 & 0.212 & 0.473 & 0.323 \\
Authoritarian parenting & 0.212 & 0.730 & -0.138 & -0.031 \\
Extraversion personality & 0.473 & -0.138 & 0.717 & 0.162 \\
Conformity & 0.323 & -0.031 & 0.162 & 0.718 \\
\hline
\end{tabular}

Based on the data in Table 4, it is known that the average variance extracted (AVE) root correlation value for each variable is higher than the average variance extracted (AVE) root correlation value with other variables. It can be said that all variables in this study meet the discriminant validity requirements.

\subsubsection{Reliability}

Reliability in PLS can be seen from the composite reliability and Cronbach alpha. A variable is said to be reliable if it has the composite reliability and Cronbach alpha values of $>0.7$ and 0.6 are still acceptable [63]. In addition, according to Cooper, the average variance extracted (AVE) value of $>0.5$ further supported reliability because by fulfilling the construct validity, the valid construct is a reliable construct [64]. The value of composite reliability and Cronbach alpha in this study can be seen in Table 5 . The data in Table 5 shows that the composite reliability and/or Cronbach alpha values on all research variables have fulfilled the requirement of $>0.6$ so that it can be concluded that all constructs or variables in this study have met the reliability requirements. 
Table 5. Reliability test results of bullying, authoritarian parenting, extraversion personality, and conformity

\begin{tabular}{lccc}
\hline \multicolumn{1}{c}{ Variable } & Composite reliability & Cronbach alpha & Explanation \\
\hline Bullying & 0.805 & 0.674 & Reliable \\
Authoritarian parenting & 0.872 & 0.823 & Reliable \\
Extraversion & 0.808 & 0.683 & Reliable \\
Conformity & 0.761 & 0.628 & Reliable \\
\hline
\end{tabular}

\subsection{Structural model test result}

This research also went through the structural model test with the inner model, aiming to ensure that the structural model that has been built is robust and accurate. The results of the inner model testing can be seen in Table 6. The results of the inner model test in Table 6 shows that the model, which correlates authoritarian parenting, extraversion personality, and conformity with bullying, exactly fit with the empirical data.

Table 6. Inner model test result

\begin{tabular}{llll}
\hline \multicolumn{1}{c}{ Criteria } & \multicolumn{1}{c}{ Role of thumb } & Value & \multicolumn{1}{c}{ Explanation } \\
\hline $\begin{array}{l}\text { Coefficient of } \\
\text { determination }\left(\mathrm{R}^{2}\right)\end{array}$ & 0.67 (strong), 0.33 (moderate), 0.19 (weak) & 0.366 & $\begin{array}{l}\text { Effect of exogenous variables on moderate } \\
\text { endogenous variables }\end{array}$ \\
$\begin{array}{l}\text { Predictive relevance }\left(\mathrm{Q}^{2}\right) \\
\text { Goodness of fit }\end{array}$ & $\mathrm{Q}^{2}>0$ (good relevance model) & 0.158 & $\begin{array}{l}\text { Good predictive relevance } \\
\text { GoF small }(0.10), \text { GoF medium }(0.25), \mathrm{GoF}\end{array}$ \\
& $\begin{array}{l}0.435 \\
\text { large }(0.36)\end{array}$ & & \\
\hline
\end{tabular}

\subsection{Hypothesis test}

Hypothesis testing is done by checking the t-statistic value against alpha 5\%, namely, t-statistics $>1.96$ and looking at the probability value of $\mathrm{p}<0.05$, indicating the hypothesis is accepted. Looking at the original sample value is also required, and if the value is $(+)$, it shows the positive influence of exogenous variables towards endogenous variables. Meanwhile, if the value is (-), it shows the negative impact of exogenous variables on endogenous variables [62]. Table 7 shows the original sample, t-statistics, and p-value.

Table 7. Hypothesis test result

\begin{tabular}{lccccc}
\hline \multicolumn{1}{c}{ Variable impact } & Original sample & T-statistic & P-value & Criteria & Explanation \\
\hline Authoritarian parenting $\rightarrow$ Bullying & 0.285 & 3.205 & 0.001 & $\mathrm{P}<0.01$ & Positive influence and very significant \\
Extraversion $\rightarrow$ Bullying & 0.470 & 7.132 & 0.000 & $\mathrm{P}<0.01$ & Positive influence and very significant \\
Conformity $\rightarrow$ Bullying & 0.256 & 3.118 & 0.002 & $\mathrm{P}<0.01$ & Positive influence and very significant \\
\hline
\end{tabular}

Based on the results of the hypothesis test in Table 7, it is known that the results of the first hypothesis test are accepted. Based on the value of $\mathrm{R}^{2}=0.366, \mathrm{Q}^{2}=0.158$, and $\mathrm{GoF}=0.435$, the theoretical model illustrates the influence of authoritarian parenting, extraversion personality, and conformity to students bullying behavior fit accordingly with empirical data. Then the results of the second hypothesis test indicate that the hypothesis is accepted. Based on the $p$-value $=0.001$ and $t$-statistic value $=3.205$ with the original sample value $=0.285$, it indicates a positive and very significant influence between authoritarian parenting and bullying in students. The results of the third hypothesis test showed that the hypothesis was also accepted. Based on the $p$-value $=0.000$ and the $t$-statistic value $=7.132$ with the original sample value $=0.470$, it shows a positive and very significant influence between extraversion personality on bullying of students. And the fourth hypothesis test results show that the hypothesis is accepted. It is based on the $p$-value $=0.002$ and $t$ statistic value $=3.118$ with the original sample value $=0.256$, which shows a positive and significant relationship between conformity and bullying.

Based on the analysis results, it is known that all hypotheses were accepted. The first hypothesis is accepted, and this result is checked against the coefficient of determination $\left(\mathrm{R}^{2}\right)$, predictive relevance $\left(\mathrm{Q}^{2}\right)$, and goodness of fit index $(\mathrm{GoF})$ so that the model of authoritarian parenting, extraversion, and conformity to bullying can be obtained. The model can show that authoritarian parenting, extraversion, and conformity very significantly affect bullying. This is in line with the goodness of fit index $(\mathrm{GoF})$ obtained, which is at a strong level.

The model produced in this study has a novelty because the model in this study is different from the model in previous studies. The model that has been examined previously is the bullying model that produces a transactional model of the relationship between maternal behavior, experiences of violence during

Int J Eval \& Res Educ, Vol. 10, No. 2, June 2021: 483 - 493 
childhood, and bullying [65]. Other studies have produced forgiveness and reconciliation (peace) models that directly predict lower bullying behavior, with adaptive shame and shame acknowledgment affecting indirect bullying [66]. In comparison to other research, the present study can arguably be said to have novelty. For example, Garandeau, et al. [67] research examine the model of the influence of class size and class status hierarchy on bullying behavior. Roland and Idsoe [68] research, furthermore, has examined the model of proactive aggressiveness, bullying others, proactive power, and proactive affiliation, which are proven to be influencing bullying behavior. Pozzoli, et al. [57] examine the effect of moral disengagement mechanisms and inter-class variability on bullying behavior.

This research also has a novelty which is resulted from the way the data are analyzed and the techniques used. In this study, data analysis was performed with partial least square (PLS). In contrast, previous studies of bullying behavior have used structural equation modeling (SEM) with the Mplus program [65], structural equation modeling (SEM) with the Amos program [66], [69], [70], structural equation modeling (SEM) with the Lisrel program [57], [68], and regression analysis with the IBM SPSS program [71]-[74].

This study's results indicate a very significant positive effect on authoritarian parenting towards bullying behavior in students. The influence of authoritarian parenting on bullying behavior is relevant to previous studies showing that authoritarian parenting has a positive effect on bullying [69]. Authoritarian parenting is characterized by assertiveness and coercion by parents related to high bullying [30] and can be a predictor of bullying [70]. Authoritarian parenting has a positive association with the experience of bullying. Lack of freedom to control oneself at home as a result of authoritarian parenting makes students engage in bullying behavior at school. That is because bullying makes an individual gain power that makes them able to control others [71].

Authoritarian parents exhibit demanding and rigid behavior but are unresponsive and do not provide support to their children so that children feel that competitiveness, power, and authoritarianism are essential to have freedom of behavior [30]. Students with authoritarian parents develop an ambiguous meaning of relationships with peers so that they tend to maintain the status of their peers by showing behavior that threatens others. Parents who do not invite their children to have a discussion also make the children experience limited ability to process information, so they do not have the ability to discuss with others to solve the problem. This makes students solve problems in ways they think is easier, namely, by using physical violence [72]. Students who often experience verbal and physical violence tend to experience the learning process of their parents' behavior and imitate them, so they tend to become perpetrators of bullying at school [75].

The result of this study also shows a very significant positive correlation between extraversion personality on bullying. This is relevant to the findings of Kokkinos, et al. [76] and Zou, et al. [77], which show that extraversion personality can be a predictor of bullying. Mitsopoulou, et al. [78] research also states that adolescents in the bullying group tend to have a high extraversion level. Besides, Scholte, et al. [79] suggest that extraversion personality is related to bullying. Other research results also show that extraversion personality is positively related to bullying [80].

Teenagers who have high extraversion tend to be popular among their friends, and they tend to do more bullying [81]. This shows that bullying actors can behave friendly and be popular among their friends [77]. Bullying is used as a means to show social dominance to others who have lower power [82]. Teenagers who have high extraversion and are in a group of bullying will also find it easier to bully others or help their friends to bully others [78]. Teenagers with a high desire to get along are always looking for stimulation from outside [83]. If this is accompanied by poor self-discipline and impulsivity, then it will encourage individuals to easily do negative things, especially to people who are considered weaker than them.

Other results from this study indicate that conformity has a positive and very significant effect on bullying. Connections with other people (connectedness) determine bullying. This is because bullying occurs with peers' support, and peer support further encourages perpetrators to do the bullying. The results of this study are relevant to the results of previous studies, which show that the desire to adjust to cultural and gender stereotypes widens the risks for teens to participate in violence [84]. Other results show that peer pressure influences adolescent involvement in bullying [85], and bullying occurs because of the need to conform [58].

There are several things that make students conform to bullying behavior such as norms, external locus of control, student attitudes towards bullying behavior, and community interaction. Norms in the classroom, for example, affect student attitudes on whether he/she will conform to bullying behavior or not. When the norms allow bullying, individuals will conform to bullying, but if the norms prohibit bullying, students will not conform [61]. Students with a low external locus of control and a positive attitude towards bullying tend to be prone to participate in bullying [60]. Besides, community orientation also influences conformity. Countries that have a higher level of collectivism tend to have a lower level of bullying. In contrast, bullying often happens in countries with high individualism levels [86]. The inability to understand bullying as an anti-social behavior also makes teens conform to bullying [59]. 
The present study is expected to bring about several implications on how we understand the negative impact of bullying and why bullying happens. It is further expected that we can restore and rebuild students' interaction patterns. Having a discussion with children and giving a logical explanation is not an easy task for parents. However, it is essential not to use force or coercion to teach their children who have different characteristics. Schools also play an essential role in training students to be able to channel their interests and talents to things that are useful. Rewards from school, such as certificates of appreciation, might as well be important for children's motivation. Schools should also understand well the dangers of bullying and how it can be overcome.

\section{CONCLUSION}

Findings from this study indicated that: 1) The model of the influence of authoritarian parenting, extraversion personality, and conformity to bullying proposed in this study is compatible with empirical data obtained at the study site; 2) There is a positive and very significant correlation between authoritarian parenting and bullying among students in Yogyakarta. The research reveals that authoritarian parenting has been found to be really influential to bullying. There is a positive and very significant relationship between extraversion personality and bullying in students in Yogyakarta. The higher the extraversion personality, the higher the bullying can get. There is a positive and very significant influence between conformity to bullying in students in Yogyakarta. The higher the conformity, the higher the bullying. Thus, the model in this study can be used as a reference to handle bullying, both theoretically and practically, especially in students or adolescents.

\section{ACKNOWLEDGEMENTS}

The authors would thank the Ministry of Research and Technology/National Research and Innovation Agency, Republic of Indonesia (RISTEK-BRIN) for providing support and funding for the completion of this research.

\section{REFERENCES}

[1] R. E. Azuine and G. K. Singh, "Mentoring, Bullying, and Educational Outcomes among US School-Aged Children 6-17 Years," The Journal of School Health, vol. 89, no. 4, pp. 267-278, 2019.

[2] D. Olweus, Bullying at School: What We Know and What We Can Do. Victoria: Blackwell Publishing, 1993.

[3] M. M. Ali, S. F. Virani and A. Alamans, "Bullying: It's Impact on Child's Personality," i-Manager's Journal on Nursing, vol. 6, no. 4, pp. 1-5, 2017.

[4] Y. Nozaki, "Why Do Bullies Matter? The Impacts of Bullying Involvement on Adolescents' life Satisfaction Via an Adaptive Approach," Children and Youth Services Review, vol. 107, p. 104486, 2019.

[5] J. A. Casas, R. Del Rey and R. Ortega-Ruiz, "Bullying and Cyberbullying: Convergent and Divergent Predictor Variables," Computers in Human Behavior, vol. 29, no. 3, pp. 580-587, 2013.

[6] S. Pabian and H. Vandebosch, "An Investigation of Short-Term Longitudinal Associations between Social Anxiety and Victimization and Perpetration of Traditional Bullying and Cyberbullying," Journal of Youth and Adolescence, vol. 45, no. 2, pp. 328-339, 2016.

[7] E. J. Connolly and K. M. Beaver, "Considering the Genetic and Environmental Overlap between Bullying Victimization, Delinquency, and Symptoms of Depression/Anxiety," Journal of Interpersonal Violence, vol. 31, no. 7, pp. 1230-1256, 2016.

[8] R. Ford, T. King, N. Priest and A. Kavanagh, "Bullying and Mental Health and Suicidal Behaviour among 14-to 15-Year-Olds in A Representative Sample of Australian Children," The Australian \& New Zealand Journal of Psychiatry, vol. 51, no. 9, pp. 897-908, 2017.

[9] H. T. H. Le, H. T. Nguyen, M. A. Campbell, M. L. Gatton, N. T. Tran and M. P. Dunne, "Longitudinal Associations between Bullying and Mental Health among Adolescents in Vietnam," International Journal of Public Health, vol. 62, no. 1, pp. 51-61, 2017.

[10] H. K. Heikkilä, J. Väänänen, M. Helminen, S. Fröjd, M. Marttunen and R. Kaltiala-Heino, "Involvement in Bullying and Suicidal Ideation in Middle Adolescence: A 2-Year Follow-Up Study," European Child \& Adolescent Psychiatry, vol. 22, no. 2, pp. 95-102, 2013.

[11] L. Hepburn, D. Azrael, B. Molnar and M. Miller, "Bullying and Suicidal Behaviors among Urban High School Youth," Journal of Adolescent Health, vol. 51, no. 1, pp. 93-95, 2012.

[12] K. L. Hutzell and A. A. Payne, "The Impact of Bullying Victimization on School Avoidance," Youth Violence and Juvenile Justice, vol. 10, no. 4, pp. 370-385, 2012.

[13] B. Gastic, "School Truancy and The Disciplinary Problems of Bullying Victims," Educational Review, vol. 60, no. 4, pp. 391-404, 2008.

[14] J. Juvonen, Y. Wang and G. Espinoza, "Bullying Experiences and Compromised Academic Performance across Middle School Grades,” The Journal of Early Adolescence, vol. 31, no. 1, pp. 152-173, 2011. 
[15] I. F. Strøm, S. Thoresen, T. Wentzel-Larsen and G. Dyb, "Violence, Bullying and Academic Achievement: A Study of 15-Year-Old Adolescents and Their School Environment," Child Abuse \& Neglect, vol. 37, no. 4, pp. 243-251, 2013.

[16] L. Townsend, A. J. Flisher, P. Chikobvu, C. Lombard and G. King, "The Relationship between Bullying Behaviours and High School Dropout in Cape Town, South Africa," South African Journal of Psychology, vol. 38, no. 1, pp. 21-32, 2008.

[17] P. R. Smokowski and K. H. Kopasz, "Bullying in School: An Overview of Types, Effects," Children \& Schools, vol. 27, no. 2, pp. 101-110, 2005.

[18] I. D. Sigfusdottir, G. H. Gudjonsson and J. F. Sigurdsson, "Bullying and Delinquency: The Mediating Role of Anger," Personality and Individual Differences, vol. 48, no. 4, pp. 391-396, 2010.

[19] M. M. Ttofi, D. P. Farrington, F. Lösel, R. V. Crago and N. Theodorakis, "School Bullying and Drug Use Later in Life: A Meta-Analytic Investigation,” School Psychology Quarterly, vol. 31, no. 1, pp. 8-27, 2016.

[20] A. Wilford, A. J. Bouton, S. S. F. Bank, K. A. Bender, W. A. Dieterich and J. M. Jenson, "The Effect of Bullying and Victimization on Cognitive Empathy Development during The Transition to Middle School," Child Youth Care Forum, vol. 45, no. 4, pp. 525-541, 2015.

[21] C. B. R. Evans, P. R. Smokowski, R. A. Rose, M. C. Mercado and K. J. Marshal, "Cumulative Bullying Experiences, Adolescent Behavioral and Mental Health, and Academic Achievement: An Integrative Model of Perpetration, Victimization, and Bystander Behavior," Journal of Child and Family Studies, vol. 27, no. 10, pp. 1-14, 2018.

[22] P. H. Hawley, "Prosocial and Coercive Configurations of Resource Control in Early Adolescence: A Case for the Well-Adapted Machiavellian,” Merrill-Palmer Quarterly, vol. 49, no. 3, pp. 279-309, 2003.

[23] D. P. Farrington and M. M. Ttofi, "Bullying as a Predictor of Offending, Violence and Later Life Outcomes," Criminal Behaviour and Mental Health, vol. 21, no. 2, pp. 90-98, 2011.

[24] E. H. Bruyn, A. H. N. Cillessen and I. B. Wissink, "Associations of Peer Acceptance and Perceived Popularity with Bullying and Victimization in Early Adolescence," The Journal of Early Adolescence, vol. 30, no. 4, pp. 543-566, 2010.

[25] K. L. Healy, M. R. Sanders and A. Lyer, "Parenting Practices, Children's Peer Relationships and Being Bullied at School," Journal of Child and Family Study, vol. 24, no. 1, pp. 127-140, 2015.

[26] B. Coloroso, The Bully, The Bullied and The Bystander. Colorado: Harper Resource, 2003.

[27] R. Dixon and P. K. Smith, Rethinking School Bullying: Towards an Integrated Model. New York: Cambridge University Press, 2011.

[28] S. N. Georgiou, M. Ioannou and P. Stavrinides, "Parenting Styles and Bullying at School: The Mediating Role of Locus of Control," International Journal of School \& Educational Psychology, vol. 5, no. 4, pp. 226-242, 2017.

[29] O. G. Ortiz, E. M. Romera and R. O. Ruiz, "Parenting Styles and Bullying: The Mediating Role of Parental Psychological Aggression and Physical Punishment," Child Abuse \& Neglect, vol. 51, pp. 132-143, 2015.

[30] I. Martínez, S. Murgui, O. F. García and F. García, "Parenting in the Digital Era: Protective and Risk Parenting Styles for Traditional Bullying and Cyberbullying Victimization," Computers in Human Behavior, vol. 90, pp. 84-92, 2019.

[31] D. Baumrind, "Authoritarian vs. Authoritative Parental Control," Adolescence, vol. 3, no. 11, p. 255, 1968.

[32] C. C. Robinson, B. Mandleco, S. F. Olsen and C. H. Hart, "Authoritative, Authoritarian, and permissive Parenting Practices: Development of a New Measure," Psychological Reports, vol. 77, no. 3, pp. 819-830, 1995.

[33] S. Moscatelli and M. Rubini, "Parenting Style in Adolescence: The Role of Warmth, Strictness, and Psychological Autonomy Granting in Influencing Collective Self-Esteem and Expectations for The Future," Handbook of Parenting: Styles, Stress \& Strategies, pp. 342-349, 2011.

[34] S. T. Lereya, M. Samara and D. Wolke, "Parenting Behavior and The Risk of Becoming A Victim and a Bully/Victim: A Meta-Analysis Study," Child Abuse \& Neglect, vol. 37, no. 12, pp. 1091-1108, 2013.

[35] P. K. Smith, "Bullying: Recent Developments," Child and Adolescent Mental Health, vol. 9, no. 3, pp. 98-103, 2004.

[36] J. S. Hong, D. H. Kim and A. R. Piquero, "Assessing The Links between Punitive Parenting, Peer Deviance, Social Isolation and Bullying Perpetration and Victimization in South Korean Adolescents," Child Abuse \& Neglect, vol. 73, pp. 63-70, 2017.

[37] A. H. Farrel, D. A. Provenzano, A. V. Dane, Z. A. Marini and A. A. Volk, "Maternal Knowledge, Adolescent Personality, and Bullying," Personality and Individual Differences, vol. 104, pp. 413-416, 2017.

[38] E. Mitsopoulou and T. Giovazolias, "Personality Traits, Empathy and Bullying Behavior: A Meta-Analytic Approach," Aggression and Violent Behavior, vol. 21, pp. 61-72, 2005.

[39] R. R. McCrae and P. T. Costa, Personality in Adulthood: A Five-Factor Theory Perspective. New York: Guilford Press, 2003.

[40] S. Boang and N. Tilopolous, Personality and Individual Differences: Theory, Assessment, and Application. New York: Nova Science Publisher, 2011.

[41] F. Tani, P. S. Greenman, B. H. Schneider and M. Fregoso, "Bullying and The Big Five: A Study of Childhood Personality and Participant Roles in Bullying Incidents," School Psychology International, vol. 24, no. 2, pp. 131-146, 2003.

[42] R. R. McCrae and P. T. Costa Jr, "Personality Trait Structure as A Human Universal," American Psychologist, vol. 52 , no. 5 , pp. 509-516, 1997 .

[43] C. Salmivalli, "Peer-led Intervention Campaign Against School Bullying: Who Considered It Useful, Who Benefited?" Educational Research, vol. 43, no. 3, pp. 263-278, 2001.

[44] R. Festl and T. Quandt, "Social Relations and Cyberbullying: The Influence of Individual and Structural Attributes on Victimization and Perpetration via The Internet," Human Communication Research, vol. 39, no. 1, pp. 101-126, 2013.

[45] D. A. Angelis, D. Bacchini and G. Affuso, "The Mediating Role of Dominant Judgement in The Relation between The Big Five and Bullying Behaviours," Personality and Individual Differences, vol. 90, pp. 16-21, 2016. 
[46] A. A. Volk, D. A. Provenzano, A. H. Farrell, A. V. Dane and E. P. Shulman, "Personality and Bullying: Pathways to Adolescent Social Dominance," Current Psychology, pp. 1-12, 2019.

[47] A. Igundunasse and O. K. Anozie, "Attachment Style and Personality Traits as Correlates of Bullying among Teenagers in Some Secondary School Settings in Lagos, Nigeria," Ife Social Sciences Review, vol. 26, no. 1, pp. 74-84, 2018.

[48] A. S. Book, A. A. Volk and A. Hosker, "Adolescent Bullying and Personality: An Adaptive Approach," Personality and Individual Differences, vol. 52, no. 2, pp. 218-223, 2012

[49] M. Van Geel, A. Goemans, F. Toprak and P. Vedder, "Which Personality Traits Are Related to Traditional Bullying and Cyberbullying? A Study with the Big Five, Dark Triad and Sadism," Personality and Individual Differences, vol. 106, pp. 231-235, 2017.

[50] J. M. Bollmer, M. J. Harris and R. Milich, "Reactions to Bullying and Peer Victimization: Narratives, Physiological Arousal, and Personality," Journal of Research in Personality, vol. 40, no. 5, pp. 803-828, 2006.

[51] M. Jia and A. Y. Mikami, "Peer Preference and Friendship Quantity in Children with Externalizing Behavior: Distinct Influences on Bully Status and Victim Status," Journal of Abnormal Child Psychology, vol. 43, no. 5, pp. 957-969, 2014.

[52] Y. Cho and O. B. Chung, "A Mediated Moderation Model of Confirmative Peer Bullying," Journal of Child and Family Study, vol. 21, no. 3, pp. 520-529, 2011.

[53] S. E. Taylor, L. A. Peplau and D. O. Sears, Social Psychology. New Jersey, 2009.

[54] R. A. Baron and N. R. Branscombe, Social Psychology, 13rd Ed. New York: Pearson, 2012.

[55] D. G. Myers, Exploring Social Psychology. New York: McGraw-Hill, 2012.

[56] S. M. Swearer and S. Hymel, "Understanding the Psychology of Bullying: Moving Toward a Social-Ecological Diathesis-Stress Model,” American Psychological Association, vol. 70, no. 4, pp. 344-353, 2015.

[57] T. Pozzoli, G. Gini and A. Vieno, "Individual and Class Moral Disengagement in Bullying Among Elementary School Children," Aggressive Behavior, vol. 38, no. 5, pp. 378-388, 2012.

[58] S. Burns, B. Maycock, D. Cross, and G. Brown, "The Power of Peers: Why Some Students Bully Others to Conform," Qualitative Health Research, vol. 18, no. 12, pp. 1704-1716, 2008.

[59] S. Cho and J. M. Lee, "Explaining Physical, Verbal, and Social Bullying Among Bullies, Victims of Bullying, and Bully-Victims: Assessing The Integrated Approach between Social Control and Lifestyles-Routine Activities Theories," Children and Youth Services Review, vol. 91, pp. 372-382, 2018.

[60] E. Kobayashi and D. P. Farrington, "Why do Japanese Bully More than Americans? Influence of External Locus of Control and Student Attitudes Toward Bullying," Educational Sciences: Theory \& Practice, vol. 20, no. 1, pp. 5-19, 2020.

[61] M. Sentse, R. Scholte, C. Salmivalli and M. Voeten, "Person-Group Dissimilarity in Involvement in Bullying and Its Relation with Social Status," Journal of Abnormal Child Psychology, vol. 35, no. 6, pp. 1009-1019, 2007.

[62] I. Ghozali and H. Latan, Partial Least Squares, Concept, Technique and Application Using Smartpls 3.0 for Empirical Research (in Bahasa). Semarang: Badan Penerbit UNDIP, 2015.

[63] J. F. Hair, G. T. M. Hult, C. M. Ringle, M. Sarstedt, N. F. Richter and S. Hauff, A primer on Partial Least Squares Structural Equation Modeling (PLS-SEM). Los Angles: Sage Publications, 2017.

[64] H. M. Jogiyanto, Concept and Application Structural Equation Modeling Varian Based in Business Research (in Bahasa). Yogyakarta: UPP STIM YKPN, 2011.

[65] S. N. Georgiou and K. A. Fanti, "A Transactional Model of Bullying and Victimization," Social Psychology of Education, vol. 13, no. 3, pp. 295-311, 2010.

[66] E. Ahmed and V. Braithwaite, "Forgiveness, Reconciliation, and Shame: Three Key Variables in Reducing School Bullying," Journal of Social Issues, vol. 62, no. 2, pp. 347-370, 2006.

[67] C. F. Garandeau, I. A. Lee and C. Salmivalli, "Inequality Matters: Classroom Status Hierarchy and Adolescents' Bullying," Journal of Youth and Adolescence, vol. 43, no. 7, pp. 1123-1133, 2014.

[68] E. Roland and T. Idsøe, "Aggression and Bullying," Aggressive Behavior, vol. 27, no. 6, pp. 446-462, 2001

[69] S. N. Georgiou, M. Ioannou and P. Stavrinides, "Cultural Values as Mediators Between Parenting Styles and Bullying Behavior at School," Social Psychology of Education, vol. 21, no. 1, pp. 27-50, 2018.

[70] K. Charalampous, C. Demetriou, L. Tricha, M. Ioannou, S. Georgiou, M. Nikiforou and P. Stavrinides, "The Effect of Parental Style on Bullying and Cyber Bullying Behaviors and The Mediating Role of Peer Attachment Relationships: A Longitudinal Study," Journal of Adolescence, vol. 64, pp. 109-123, 2018.

[71] M. Garaigordobil and J. M. Machimbarrena, "Stress, Competence, and Parental Educational Styles in Victims and Aggressors of Bullying and Cyberbullying," Psicothema, vol. 29, no. 3, pp. 335-340, 2017.

[72] M. F. Alizadeh, M. Mirnasab and T. Hashemi, "The Predictive Role of Maternal Parenting and Stress on Pupils' Bullying Involvement," Journal of Interpersonal Violence, vol. 34, no. 17, pp. 3691-3710, 2019.

[73] N. F. A. Rokoyah and D. Hastuti, "Mother's Parenting Style and Television Media Access Determining Bullying Behavior on Elementary School Children," Jurnal Ilmu Keluarga \& Konsumen, vol. 12, no. 1, pp. 52-62, 2019.

[74] I. Krisnana, P. D. Rachmawati, Y. S. Arief, I. D. Kurnia, A. A. Nastiti, I. F. N. Safitri and A. T. K. Putri, "Adolescent Characteristics and Parenting Style as The Determinant Factors of Bullying in Indonesia: A CrossSectional Study," International Journal of Adolescent Medicine and Health, pp. 1-9, 2019.

[75] I. Tajuddin, K. A. Utami and Y. Arafat, "The Effect of Parenting Style on Bullying Behavior," 8th International Conference of Asian Association of Indigenous and Cultural Psychology (ICAAIP 2017), vol. 127, pp. 280-284, 2017.

[76] C. M. Kokkinos and N. Antoniadou, "Cyber-Bullying and Cyber-Victimization among Undergraduate Student Teachers through the Lens of the General Aggression Model," Computers in Human Behavior, vol. 98, pp. 59-68, 2019. 
[77] M. Zou and M. G. Shahnawaz, "Personality and Connectedness as Predictors of School Bullying among Adolescent Boys," Journal of Indian Association for Child \& Adolescent Mental Health, vol. 10, no. 4, pp. 249-270, 2014.

[78] E. Mitsopoulou and T. Giovazolias, "Personality Traits, Empathy and Bullying Behavior: A Meta-Analytic Approach," Aggression and Violent Behavior, vol. 21, pp. 61-72, 2015.

[79] R. H. Scholte, C. F. van Lieshout, C. A. de Wit and M. A. van Aken, "Adolescent Personality Types and Subtypes and Their Psychosocial Adjustment," Merrill-Palmer Quarterly, vol. 51, no. 3, pp. 258-286, 2005.

[80] A. Mazzone and M. Camodeca, "Bullying and Moral Disengagement in Early Adolescence: Do Personality and Family Functioning Matter?” Journal of Child and Family Studies, vol. 28, no. 8, pp. 2120-2130, 2019.

[81] A. L. Duffy, S. Penn, D. Nesdale and M. J. Zimmer-Gembeck, "Popularity: Does It Magnify Associations between Popularity Prioritization and The Bullying and Defending Behavior of Early Adolescent boys and Girls?" Social Development, vol. 26, no. 2, pp. 263-277, 2017.

[82] A. A. Volk, K. Schiralli, X. Xia, J. Zhao and A. V. Dane, "Adolescent Bullying and Personality: A Cross-Cultural Approach," Personality and Individual Differences, vol. 125, pp. 126-132, 2018.

[83] A. Fossati, S. Borroni and C. Maffei, "Bullying as a Style of Personal Relating: Personality Characteristics and Interpersonal Aspects of Self-Reports of Bullying Behaviours among Italian Adolescent High School Students," Personality and Mental Health, vol. 6, no. 4, pp. 325-339, 2012.

[84] R. Navarro, E. Larrañaga and S. Yubero, "Gender Identity, Gender-Typed Personality Traits and School Bullying: Victims, Bullies and Bully-Victims," Child Indicators Research, vol. 9, no. 1, pp. 1-20, 2016.

[85] A. Y. Loke, Y. W. Mak and C. S. T. Wu, "The Association of Peer Pressure and Peer Affiliation with The Health Risk Behaviors of Secondary School Students in Hong Kong," Public Health, vol. 137, pp. 113-123, 2016.

[86] H. Huang, J. S. Hong and D. L. Espelage, "Understanding Factors Associated with Bullying and Peer Victimization in Chinese Schools within Ecological Contexts," Journal of Child and Family Studies, vol. 22, no. 7, pp. 881-892, 2013. 